\title{
Academic Librarianship in Three Education Journals
}

\begin{abstract}
In an attempt to determine the profile of academic librarianship presented in the periodical literature of higher education, articles on the subject were sought in three journals: The Journal of Higher Education, Liberal Education, and Higher Education. The first two each carried an average of 1.25 such papers annually, but Higher Education published somewhat fewer. Inadequate support, status for librarians, and poor institutional cooperation have been well presented, but the ninety-four papers found were repetitious. The author concludes that: 1) a mixed picture of librarianship results; 2) such papers are due more attention than they have had within the profession; and 3) librarians should write more for non-library journals.
\end{abstract}

L of the acsemic world has hed little awareness of the tremendous changes that have been taking place during the last few decades in the field of library service. Perhaps they are right, but the question arises-Have librarians made a serious attempt to communicate with others about their profession? More specifically, what sort of picture of librarianship has been presented to educators in the periodical literature of higher education? In the hope of supplying a partial answer to these and similar questions, a search was made for articles on academic librarianship in three of the best known journals devoted to college and university education: The Journal of Higher Education (vols. 1-36, 1930-65), Liberal Education $^{1}$ (vols. 16-51, 1930-65), and Higher Education (vols. 1-20, 194564)..$^{2}$

${ }^{1}$ Prior to 1961 Liberal Education was known as the Association of American Colleges Bulletin.

${ }^{2}$ See also the literature survey in Floyd Smith, Jr., "The Library in the Junior College Journal: an Evaluation," Junior College Journal, XXVII (September 1956), 39-41.

Mr. Holland is Chairman, Department of Library Science, Appalachian State Teachers College, Boone, North Carolina.
The Journal of Higher Education, appearing nine times a year, published a total of forty-five articles on libraries and librarianship in thirty-six years, or about 1.25 articles per year. This does not include, however, the excellent series of review articles by Maurice Tauber which have been appearing three times a year since April 1962. The forty-five articles have been written by forty-four different authors (including two "joint authors"), with only Carl M. White, Guy R. Lyle, and Robert Lightfoot, Jr. contributing more than one each. Eight authors (18 per cent) were not librarians: they were either professors, academic administrators, or members of other professions. The number of articles on librarianship published during a single year ranged from zero to five. Fourteen articles appeared during the decade 1930-39, eighteen during 1940-49, and ten during 1950-59.

During the same thirty-six year period Liberal Education, a quarterly, published a total of forty-four articles, written by thirty-six authors of whom nine ( 25 per cent) were non-librarians. Henry W. Wriston furnished four articles, and William Warner Bishop, Harvie 
Branscomb, Stith M. Cain, Robert M. Lester, and Rodolfo O. Rivera two each. The annual production for this journal also ranged from zero to five. Twentytwo articles appeared during the 1930's, nine during the 1940 's, and eight in the 1950's.

Higher Education, published monthly during the school year by the US Office of Education, ceased publication with the issue for June $1964 .^{3}$ It was essentially a carrier of news, notices, and reviews rather than a repository of articles, so that during its lifetime of twenty and one-half years it published only five fullscale articles on librarianship (about one article every four years). These were substantial articles however, including two by Willard O. Mishoff on library education (1948, 1952), an analysis of academic library statistics by Theodore Samore (1963), an article on library buildings by Ralph E. Ellsworth (1949), and one on the Midwest Interlibrary Center by Ralph T. Esterquest (1950). Since three of the five articles were written by library specialists at the Office of Education, the publication was obviously not a good outlet for articles by other librarians.

The Journal of Higher Education and Liberal Education have published almost the same number of library articles between 1930 and 1965. But Liberal Education, being published less frequently, must be judged the more generous in its space allotment. It has also seen in its pages more support of librarianship by non-librarians. On the other hand, The Journal of Higher Education has allowed a more consistent coverage year by year. The late Charles C. Williamson, one-time dean of the Columbia University school of library service, was a member of its editorial board from the very beginning of publication. Mau-

\footnotetext{
Higher Education has been superseded by American Education which began publication with an issue for Dec. 1964/Jan. 1965.
}

rice Tauber, Melvil Dewey professor of library service at Columbia, now serves as a corresponding editor.

The following list indicates, by means of rough (and in some cases arbitrary) groupings, the approximate rank order of subjects covered by the ninety-four articles:

EDUCATIONAL FUNCTIONS OF THE LIBRARY:

JHE-Cowley 1936; Danton 1937; Lyle 1941; Hoole 1943; Mattis 1952; "One Who Knows" 1953; Wilson and Samson 1955.

LE-Gilchrist 1933; Hammond 1936; Bishop 1937; Wriston 1937; Branscomb 1937; Branscomb 1939; Lester 1940; Park 1946; Land 1946; Schulze 1948; Rush 1950; Knapp 1960; Chen 1960.

READER SERVICES (MOSTLY INSTRUCTION IN USE OF THE LIBRARY):

JHE-Smith 1936; White 1937; Fenton 1938; Meyering and Pierson 1939; Wilde 1940; Seeger 1941; Garloch 1942; Young 1942; Schindler 1943; Buechler 1958.

LE-Wriston 1937; Jones 1946.

LIBRARIANS (INCLUDING EDUCATION, STATUS, PERSONAL QUALITIES):

JHE-Wilkins 1934; Falley 1937; Rossell 1940; Thompson 1943; White 1945. LE-Snavely 1937; Diehl 1955; Vosper 1957.

HE-Mishoff 1948; Mishoff 1952.

FACULTY AND THE LIBRARY:

JHE-Waples 1930; Barksdale 1942; Baker 1948; McMullen 1954; Lightfoot 1959; Lightfoot 1960.

LE-Wriston 1931; Wriston 1932; Barnett 1959.

TECHNICAL SERVICES (SELECTION, ACQUISITION, CATALOGING OF MATERIALS):

JHE-Brown 1931; Donohue 1942; Jackson 1943; Tauber 1961. 
LE-Walkley 1931; Norton 1936; Reynolds 1963.

LIBRARY COOPERATION (REGIONAL SYSTEMS, UNION LISTS, STORAGE LIBRARIES, ETC.):

JHE-Lyle 1934; Wilson 1951; Ellsworth 1952; Esterquest 1953.

LE-Rivera 1942; McCain 1962.

HE-Esterquest 1950.

\section{BUILDINGS:}

JHE-Kilham 1948; Hodgson 1957.

LE-McCain 1935; Ewing 1936; Gores 1963.

HE-Ellsworth 1949.

SURVEYS, STANDARDS, STATISTICS:

JHE-Walter 1931.

LE-Kelly 1932; Rider 1940; Taube 1942; Weber 1957.

HE-Samore 1963.

PHILANTHRopic FOUNDATIONS:

JHE-Randall 1933.

LE-Bishop 1930; Adams 1936; Lester 1939; Ludington 1957.

STUDENT USE OF THE LIBRARY:

JHE-Eurich 1933; White 1962.

LE-Butler 1963.

ORGANIZATION OF THE LIBRARY:

JHE-Jesse 1944; Land 1947.

LE-Johnson 1935.

ACADEMIC ADMINISTRATORS AND THE LIBRARY:

LE-Danton 1937; Cain 1951; Cain 1952.

\section{RESOURCES:}

\section{LE-Stowe 1930; Rivera 1941.}

Public RELATIONS:

JHE-Bixler 1943.

Librarians-and occasionally colleagues among faculty and administration-have attempted to depict academic librarianship with a commendable regularity and persistence. Such perennial problems as inadequate support, lack of academic status, and insufficient cooperation have been attacked with conviction and candor. Also on the positive side, it should be pointed out that the majority of the articles are straightforward, serious, and practical in their approach, with almost no attempts to ascend into rarefied, over-speculative atmospheres. Many of the articles are well written from the standpoint of both organization and content.

On the negative side, it must be confessed that the picture of librarianship offered by the ninety-four articles is repetitious. The academic world must surely be tired of hearing that librarians are educators and not mere custodians, that most students need instruction in use of the library, and that the assignments of inconsiderate professors cause headaches for reserve book librarians. The (apocryphal?) college president who first proclaimed the library as the "heart of the college" should henceforth be anathema to librarians because of the endless series of remarks he thereby produced. Other clichés have become equally tiresome. Some of the articles are unbearably dull, particularly those that try (with varying degrees of success) to cover the entire field of librarianship. Far too many are dyspeptic in tone. Only those by Ellen Jackson, Robert Lightfoot, and Haynes McMullen stand out for their successful attempts at humor.

Three conclusions are in order.

First, the picture has been mixed. The spirit ranges from the apologetic to the defiant. A fairly wide variety of topics has been covered, but many vital areas of librarianship have been either poorly presented or ignored altogether. Others have been overworked. Although there have been numerous articles on instruction in use of the library, a non-librarian 
who read all ninety-four articles would still have little comprehension of such basic things as library circulation and reference work. Much still needs to be said about such topics as the intellectual delights of work in the profession, the problems inherent in the classification and other organization of information, the challenges and opportunities afforded by newer media of communication, the solid developments in library technology, and the very bright prospects for the future.

Second, library school students must learn to include education journals in their searches and studies. Outstanding librarians have contributed to them. Non-librarians writing on library topics often provide freshness and perspective. Third, librarians should publish more in education journals. It is obvious from even this short survey that such articles are welcomed by editors. They should be written without benefit of either esoteric jargon, martyr complex, or obvious chip-on-the-shoulder. Educators do not have time to read library journals; librarians have a responsibility to place articles where the educators will be reading.

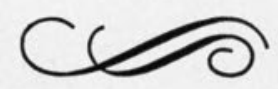

